\title{
STRATEGIC ANALYSIS OF INTELLIGENT TRANSPORTATION SYSTEMS
}

\author{
Esin MUKUL ${ }^{1}$, Gülçin BÜYÜKÖZKAN², Merve GÜLER ${ }^{3}$
}

\begin{abstract}
Transportation is one of the most critical factors affecting the economic development and welfare of a country. Effective transport systems create socio-economic opportunities and benefits by facilitating access to markets, jobs, and investments. Moreover, transportation shows a rapid change in today's world of globalization and economic growth. With the rapid development of information and technology, the demand for higher, faster, safer, and more comfortable transportation is emphasized. On the other hand, with the development of the automotive industry, increased vehicle traffic volumes cause congestion, delays, travel time, resource consumption, environmental problems, and accidents. Systems need to be designed to be more efficient, effective, safe, and economical to reduce these adverse outcomes of transportation systems and meet user demands. For this reason, the concept of "Intelligent Transportation Systems (ITS)" has emerged. ITS provide economic, environmental, and socially sustainable solutions, in particular by ensuring that information is accessed quickly and efficiently. The analysis of ITS are very complicated since it has many conflicting objectives and many different criteria. Multi-criteria decision-making (MCDM) is a powerful tool widely used for solving this type of problems. Therefore, in this study, we aim to propose a strategic analysis of ITS by using MCDM methods. In the proposed methodology, ITS criteria are weighted with fuzzy Analytic Hierarchy Process (AHP) and fuzzy Evaluation Based on Distance from Average Solution (EDAS) is used to select the most appropriate ITS strategy. Finally, an application is provided to demonstrate the potential use of the proposed methodology.
\end{abstract}

Keywords:Fuzzy logic, intelligent transportation systems, MCDM methods, strategic analysis

Jel Classification: L10, L21, L91

\section{AKILLI ULAŞIM SISTEMLERININ STRATEJIK ANALIZI}

\section{$\ddot{O} z$}

Ulaşım, bir ülkenin ekonomik kalkınmasını ve refahını etkileyen en kritik faktörlerden biridir. Etkili ulaştırma sistemleri pazarlara, işlere ve yatırımlara erişimi kolaylaştırarak sosyoekonomik firsatlar ve faydalar yaratmaktadır. Küreselleşme ve ekonomik büyüme ile beraber ulaşım sektörü de hızlı bir değişim göstermektedir. Bilgi ve teknolojinin hızla gelişmesiyle birlikte, daha kaliteli, daha hızlı, daha güvenli ve daha rahat ulaşım talepleri ön plana çıkmaktadır. Öte yandan, otomotiv endüstrisinin gelişmesiyle birlikte artan araç trafiği yoğunluğu; tıkanıklığa, gecikmelere, seyahat süresinin uzamasına, kaynak tüketiminin artmasına, çevresel sorunlara ve kazalara neden olmaktadır. Ulaşım sistemlerinin bu olumsuz sonuçlarını azaltmak ve kullanıcı taleplerini karşılamak için sistemlerin daha verimli, etkili, güvenli ve ekonomik olacak şekilde tasarlanmasi gerekmektedir.

1 Research Asst. Esin Mukul, Galatasaray University, Faculty of Engineering and Technology, Department of Industrial Engineering, Istanbul, Turkey, emukul@gsu.edu.tr, ORCID: 0000-0003-48358821.

2 Prof. Dr. Gülçin Büyüközkan, Galatasaray University, Faculty of Engineering and Technology, Department of Industrial Engineering, Istanbul, Turkey, gulcin.buyukozkan @ gmail.com, ORCID: 00000002-2112-3574.

3 Resarch Asst. Merve Güler, Galatasaray University, Faculty of Engineering and Technology, Department of Industrial Engineering, Istanbul, Turkey, mguler@ gsu.edu.tr, ORCID: 0000-0003-16641139. 
Bu sorunların giderilmesi ve taşımacılık hizmetlerinde artan talebin etkin, güvenli ve çevreci bir şekilde karşılanması amacıyla bilgi ve iletişim teknolojileri kullanılarak geliştirilen Akı1lı Ulaşım Sistemleri (AUS) özellikle bilgiye daha hızlı ve etkin bir şekilde erişmeyi sağlayarak, ekonomik, çevresel ve toplumsal açıdan sürdürülebilir çözümler sunmaktadır. Çok sayıda çelişkili amacı ve birçok farklı kriteri bünyesinde barındırdığı için AUS'un analizi oldukça karmaşıktır. Çok kriterli karar verme (ÇKKV) bu tür problemleri çözmek için yaygın olarak kullanılan güçlü bir araçtır. Bu çalışmanın amacı, ÇKKV yöntemleri kullanarak AUS'un stratejik analizini yapmaktır. Önerilen metodolojide, AUS değerlendirme kriterleri bulanık Analitik Hiyerarşi Süreci (AHP) metodu ile ağırlıklandırılmakta ve bulanık EDAS (Evaluation Based on Distance from Average Solution) metodu ile en uygun AUS stratejisi seçilmektedir. Son bölümde, önerilen metodolojinin kullanım potansiyelini göstermek için bir uygulama sunulmaktadır.

Anahtar Kelimeler: Akıllı ulaşım sistemleri, bulanık mantık, ÇKKV yöntemleri, stratejik analiz

Jel Sinıflama: L10, L21, L91

\section{Introduction}

Transportation is one of the most critical factors affecting the economic development and welfare of a country. Effective transport systems create socio-economic opportunities and benefits by facilitating access to markets, jobs, and investments. Transportation shows a rapid change in today's world, with globalization and economic growth. With the rapid development of information and technology, the demand for higher, faster, safer, and more comfortable transportation is emphasized (Zhang et al., 2011). On the other hand, with the development of the automotive industry, increased vehicle traffic volumes cause congestion, delays, travel time, resource consumption, environmental problems and accidents (Yardım and Akyıldız, 2005). Systems need to be designed to be more efficient, effective, safe, and economical to reduce these adverse outcomes of transportation systems and meet user demands. For this reason, the concept of "Intelligent Transportation Systems (ITS)" has emerged (Wang, 2010).

ITS provide economic, environmental, and socially sustainable solutions, in particular by ensuring that information is accessed quickly and efficiently. The objectives of ITS are

to provide multidimensional data exchange between human-vehicle-infrastructure-center,

to use in accordance with the capacities of roads,

to increase the safety and mobility of traffic,

to reduce energy loss

to the environment by providing energy efficiency.

Within the context of ITS, solutions to significant transportation problems can be produced by using advanced information and communication technologies. With ITS applications, coordination between different types of transportation can be provided to create ideal traffic conditions, and the efficiency and speed of services related to passenger and freight movements can be increased (UHDB, 2014).

Choosing the right strategy provides access to integrated, secure, efficient, innovative, human, and environmentally friendly, sustainable, and smart transportation networks using that are well integrated with information and communication technologies. 
ITS strategy selection problem has many conflicting objectives, where different criteria need to be taken into account for deciding on the right strategy.

Transportation networks are exposed to uncertainty environments. Therefore, the need for robustness, flexibility, and agility has become a focal point for future logistics system designs. ITS solutions such as strategies have developed to reduce the harmful effects of increased transport in urban areas (Kirch et al.,2017). In this study, ITS strategy selection problem is considered as a fuzzy multi-criteria decision-making (MCDM) problem.

MCDM is a powerful tool, which is widely used for evaluating problems containing multiple, usually conflicting criteria. It refers to find the best opinion from all of the feasible alternatives. Priority-based, outranking, distance-based, and mixed methods could be considered as the primary classes of the current methods (Pomerol and Romero, 2000).

The mixed structure of the ITS strategies evaluation involves many various and contradictory criteria. However, it is challenging to decide on, and rank alternatives when information is in an uncertain nature. Sometimes decision-makers (DMs) have difficulties in expressing their thoughts by crisp numbers. Furthermore, DMs can express their opinions more comfortably with fuzzy numbers. It overcomes the uncertainty of this MCDM problem.

In this study, firstly ITS criteria are determined with literature review and expert opinions. These criteria are weighted by using fuzzy Analytic Hierarchy Process (AHP). After that, according to ITS concept, ITS strategies are identified with literature review and expert opinions and the most appropriate ITS strategy is selected by using fuzzy Evaluation Based on Distance from Average Solution (EDAS). The study aims to propose a new analytic methodology for strategic analysis of ITS and present fuzzy EDAS method combined fuzzy AHP.

The structure of the paper is as follows: The related studies about ITS are summarized in the next section. Section 3 presents the proposed model and methodology. Application is given in Section 4, and finally, the last section concludes the study.

\section{Intelligent Transportation Systems}

ITS can be defined as transportation solutions designed to alleviate the thinking or decisionmaking burden on people. From this point of view, the first ITS application is traffic lights with electric that were first used in 1928. With the traffic lights, problems such as the priorities of the vehicles and the pedestrians of the highways, passing times, etc. have been resolved. Thus, traffic lights take on the task of thinking and deciding of the pedestrians and drivers. Today, ITS refers to systems based on the use of electronic and computer technology in transportation regulation and management (Civitas, 2015).

Today, ITS are built on advanced technologies such as computers, communications, and electronics. They are systems that use real-time and up-to-date databases and services to improve efficiency, security, and service quality in transportation. On the other hand, the integration of all transport systems on technological and institutional basis enables people and goods to move from one place to another, is also considered within the concept of ITS (Yardım and Aky1ldız, 2005).

With ITS, timesaving and more environmentally friendly transportation are provided, and at the same time, the quality of the journeys is enhanced. 
ITS improves the performance of modern transport systems by optimizing travel times and reducing the risk of crashes and injuries. ITS applications increase the efficiency of road infrastructure by reducing the costs of infrastructure. They increase travel options and mobility by combining travel information and effective demand management (Zanelli, 2016).

In the literature, Bask et al. (2008) proposed the conceptual model of the ITS management and analyzed how the included factors change the performance of distribution activities and what management issues are at stake. Kim et al. (2010) proposed a reservation-based scheduling scheme for the ITS charging station to decide the service order of multiple requests. Synergizing electrified vehicles and mobile information systems in ITS are presented bySchewel and Kammen (2010). Kumbhar (2012) developed Wireless sensor networks for ITS solution. Wang and Kexin (2013) discussed the benefits and problems of the three solutions of transportation, based on the Transit Priority Strategy in China, including the transportation policy research, smart transportation research, as well as planning and design research. Kolosz et al. (2013) made a model of ITS for highways using probabilistic data fusion. Bacciu et al. (2017) analyzed the feasibility of these services in using machine learning for short-term predictions in ITS.

There are many studies about ITS in the literature. In this study, ITS concept is handled with a different perspective, and this concept is combined with MCDM methods for the first time.

\section{The Proposed Model And Methodology}

The proposed approach in this study consists of four basic steps:

Step 1. Determination of proposed ITS model with literature review and expert opinions.

Step 2. Calculation of the weights of ITS criteria with fuzzy AHP.

Step 3. Determination of ITS strategies with literature review and expert opinions.

Step 4. Evaluation of ITS strategies and selection of the most appropriate ITS strategy with fuzzy EDAS.

\section{The Proposed ITS Model}

As a result of the literature review and expert opinions, the ITS structure (UHDB, 2014; Dia and Panwai, 2014; Catapult, 2014; Civitas, 2015; Bacciu et al., 2017) is shown as in Figure 1.

In this model, there are four main criteria: cost, capacity congestion and connection. These main criteria are determined by taking into the essential components of ITS. Besides, there exist twenty sub-criteria of these main criteria. 

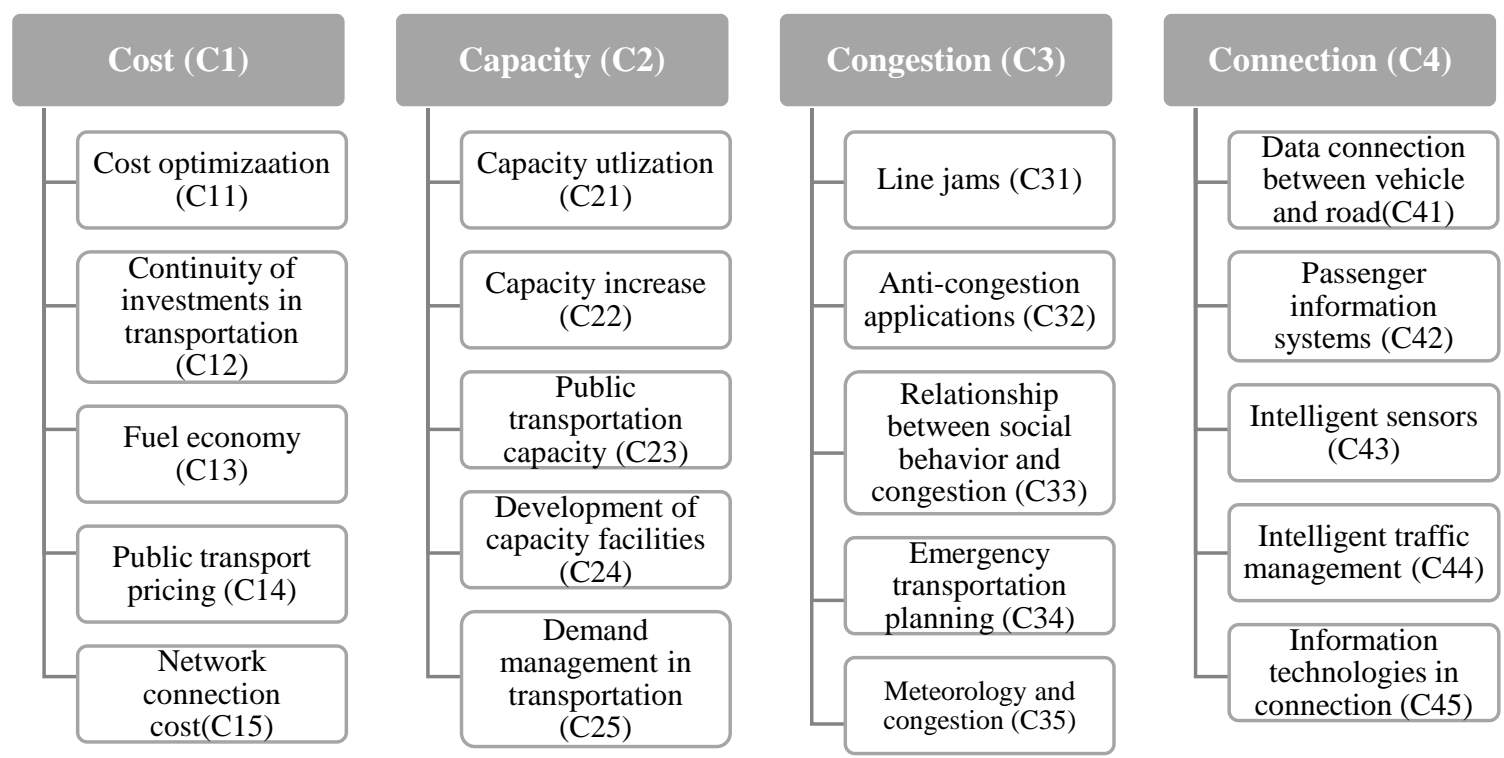

Figure 1.The Proposed ITS Model.

\section{The Fuzzy AHP Method for Calculation of Criteria Weights}

AHP is developed by Saaty (1980) probably the best-known and most widely used model in decision-making. AHP is a robust decision-making methodology in order to determine the priorities among different criteria.

Fuzzy AHP is a method that will allow decision-makers to make decisions in an MCDM process and facilitate decision-making in uncertain situations (Ayağ, 2005). When the literature is examined, it is seen that different authors present many different fuzzy AHP methods.

Fuzzy AHP used in this study includes the following steps (Büyüközkan and Çif̧ci, 2012):

Step 1: Construct the fuzzy comparison matrices by using triangular fuzzy numbers in Table 1 .

Table 1.The Fuzzy Scale

\begin{tabular}{|l|l|}
\hline Linguistic expression & Fuzzy Scale \\
\hline Extremely more importance & $(8,9,10)$ \\
\hline Very strong importance & $(6,7,8)$ \\
\hline Strong importance & $(4,5,6)$ \\
\hline Moderate importance & $(2,3,4)$ \\
\hline Equal importance & $(1,1,2)$ \\
\hline
\end{tabular}

Step 2: $\alpha$-cut matrices are constructed. The $\alpha$-cut is known to incorporate decision-makers' confidence over his/her preferences. The index of optimism $\mu$ estimates the degree of satisfaction for the judgment matrix. A larger value of the index $\mu$ indicates a higher degree of optimism. 
The index of optimism is a linear convex combination defined as

$$
\tilde{a}_{i j}^{\alpha}=\mu \tilde{a}_{i j l}^{\alpha}+(1-\mu) \tilde{a}_{i j l}^{\alpha} \forall \alpha \in[0,1]
$$

Step 3: Matrices are normalized using (2) and the consistency ratio (CR) for each matrix are calculated.

$$
\begin{aligned}
\tilde{r}_{i j} & =\frac{\tilde{a}_{i j}^{\alpha}}{\sum_{i}^{k} \tilde{a}_{i j}^{\alpha}} \\
C I & =\frac{\lambda_{\max }-n}{n-1} \\
C R & =\frac{C I}{R I}
\end{aligned}
$$

where $C I$ refers to consistency index, $\lambda_{\max }$ is the largest eigenvector of the matrix, $\mathrm{n}$ is the number of criteria, and $R I$ is the random index.

Step 4: The weights of main criteria $\left(\widetilde{w}_{i}{ }^{C R}\right)$ are obtained using arithmetic mean. And, these steps are applied for each sub-criteria and global weights $\left(\widetilde{w}_{i j}^{G}\right)$ are calculated by multiplying the weight of main criteria.

$$
\widetilde{W}_{i j}^{G}=\widetilde{W}_{i}^{C R} \times \widetilde{w}_{j}^{C R}
$$

\section{ITS Strategies}

Many strategies can be used to realize the integration of ITS. In this case, it is vital to choose the strategy that will be most successful and the most appropriate for the system. These strategies are as follows:

Intelligent public transport systems (A1): The system that enables the most convenient use of the public transportation needs that arise with the increasing population. Passenger information systems and electronic payment systems are the most common methods used in public transport. These systems include smart stops and contactless smart cards (UNECE, 2012).

Network communication systems (A2): It provides communication between the area and central equipment of ITS. This connection can be reached with wired and wireless networks. The communication systems solutions offered by İSBAK are fiber optic solutions, 4G / LTE, 3G, Wi-Fi, and WIMAX (Ilıcalı et al., 2016). In many countries, metropolitan areas have mobile and web applications that provide instant information about the traffic situation. Along with these applications, users can be informed and easily use ITS.

Security and emergency systems (A3): It detects and prevents emergency intervention events such as traffic accidents. Security systems consisting of cruise control systems and anti-lock braking systems have developed. New generation systems such as emergency brake-force distribution, electronic stability control, and advanced speed control systems have designed (UHDB, 2014).

Full adaptive traffic management systems (A4): It is a working system in which the parameters have optimized for minimizing average vehicle delay times and average stop numbers.

It accelerates traffic flow by intervening in real-time on blocked roads and reduces delay times. It reduces travel time and emissions on the road network (Khan, 2012; Catapult, 2014). 


\section{The Fuzzy EDAS Method for Evaluation of Strategies}

EDAS method is introduced by Ghorabaee et al. (2015) tested the validity of this method. This method considers the average solution for the evaluation of alternatives. It is also a distancebased method.

In literature, the EDAS method with fuzzy logic is proposed by Ghorabaee et al. for supplier selection (2016). The EDAS method was also combined with the advanced methods in the literature. In addition, hesitant fuzzy EDAS is proposed with different aggregation operators with defuzzification and without-defuzzification processes for hospital selection (2018).

The steps of the fuzzy EDAS method are presented as follows (Ghorabaee et al., 2016):

Step 1: The matrix between criteria and alternatives are constructed by using a fuzzy scale in Table 1 .

Step 2: The matrices of positive distance from average (PDA) and negative distance from average (NDA) are calculated. $B$ is the set of beneficial criteria, and $N$ is the set of non-beneficial criteria.

$$
\begin{aligned}
& \widetilde{p d a_{i j}}= \begin{cases}\frac{\psi\left(\tilde{x}_{i j} \ominus \widetilde{a v}_{j}\right)}{\kappa\left(\widetilde{a v}_{j}\right)} & \text { if } j \in B \\
\frac{\psi\left(\widetilde{a v}_{j} \ominus \tilde{x}_{i j}\right)}{\kappa\left(\widetilde{a v}_{j}\right)} & \text { if } j \in N\end{cases} \\
& \widetilde{n d} a_{i j}= \begin{cases}\frac{\psi\left(\widetilde{a v}_{j} \Theta \tilde{x}_{i j}\right)}{\kappa\left(\widetilde{a v}_{j}\right)} & \text { if } j \in B \\
\frac{\psi\left(\widetilde{x}_{i j} \ominus \widetilde{a v}_{j}\right)}{\kappa\left(\widetilde{a v}_{j}\right)} & \text { if } j \in N\end{cases}
\end{aligned}
$$

where $\widetilde{a v}_{j}$ represents the average solutions matrix and $\kappa\left(\widetilde{a v}_{j}\right)$ represents the defuzzified number.

Step 3: Calculate the weighted sum of positive and negative distances.

$$
\begin{aligned}
& \widetilde{s p}_{i}=\bigoplus_{j=1}^{m}\left(\widetilde{w}_{j} \otimes p \widetilde{d} a_{i j}\right) \\
& \widetilde{s n}_{i}=\bigoplus_{j=1}^{m}\left(\widetilde{w}_{j} \otimes \tilde{n d} a_{i j}\right)
\end{aligned}
$$

Step 4: Normalize the values for all alternatives.

$$
\begin{aligned}
\widetilde{n s p}_{i} & =\frac{\widetilde{s p}_{i}}{\max _{i}\left(\kappa\left(\widetilde{s p}_{i}\right)\right)} \\
\widetilde{n s n}_{i} & =1-\frac{\widetilde{s n}_{i}}{\max _{i}\left(\kappa\left(\widetilde{s n}_{i}\right)\right)}
\end{aligned}
$$

Step 5: Calculate the appraisal score $\left(\widetilde{a s}_{i}\right)$ for all alternatives.

$$
\widetilde{a s}_{i}=\frac{1}{2}\left(\widetilde{n s p}_{i} \oplus \widetilde{n S n}_{i}\right)
$$

Step 6: Rank the alternatives according to the appraisal values.

Application

The proposed methodology is applied to verify its usability. There is a company named as 'ABC' plans to invest in the field of ITS in Istanbul. They want to see the ITS of Istanbul with all environmental factors and to select the best strategy for ITS. There are five possible alternatives in which to select the strategy: A1 intelligent public transport systems. 
A2 is a network communication system. A3 is security and emergency systems, and A4 is full adaptive traffic management systems.

Fuzzy AHP-Step 1: As a starting point, ITS model is constructed with literature review and expert opinions as Figure 1. Then, the fuzzy comparison matrix between these criteria is structured by using triangular fuzzy numbers in Table 1 . The comparison matrix for the main criteria is shown in Table 2.

Table 2.The Comparison Matrix for Main Criteria

\begin{tabular}{|l|l|l|l|l|l|l|l|l|l|l|l|l|}
\hline & \multicolumn{3}{l}{ C1 } & \multicolumn{3}{l}{ C2 } & \multicolumn{3}{l|}{ C3 } & \multicolumn{3}{l|}{ C4 } \\
\hline C1 & 1.00 & 1.00 & 1.00 & 0.50 & 1.00 & 1.00 & 0.5 & 0.33 & 0.50 & 0.13 & 0.14 & 0.17 \\
\hline C2 & 1.00 & 1.00 & 2.00 & 1.00 & 1.00 & 1.00 & 0.17 & 0.20 & 0.25 & 0.17 & 0.20 & 0.25 \\
\hline C3 & 2.00 & 3.00 & 4.00 & 4.00 & 5.00 & 6.00 & 1.00 & 1.00 & 1.00 & 1.00 & 1.00 & 2.00 \\
\hline C4 & 6.00 & 7.00 & 8.00 & 4.00 & 5.00 & 6.00 & 0.50 & 1.00 & 1.00 & 1.00 & 1.00 & 1.00 \\
\hline
\end{tabular}

Fuzzy AHP-Step 2: $\alpha$-cut matrices $(\alpha=0.5 ; \mu=0.5)$ are constructed by using (1) and these matrices are normalized.

Fuzzy AHP-Step 3: CR is checked.

Fuzzy AHP-Step 4: These steps are applied for all sub-criteria, and final global weights for all criteria are calculated. Final criteria weights are shown in Table 3.

According to final weights, the most appropriate criteria are "emergency transportation planning (C34)", "information technologies in connection (C45)" and "line jams (C31). In particular, the weights of C34 and C45 are considerably higher than the others. These criteria have an essential place for determination of the strategies.

Fuzzy EDAS-Step 1: The matrix between criteria and alternatives are constructed by using a fuzzy scale in Table 1 .

Fuzzy EDAS-Step 2-3: The PDA and NDA matrices are constructed by using (6) and (7) and $\widetilde{s p}_{i}$ and $\widetilde{s n}_{i}$ values are computed with (8) and (9).

Fuzzy EDAS-Step 4-5-6: $\widetilde{n s p}{ }_{i}, \widetilde{n s n_{i}}$ and $\widetilde{a s}$ values are calculated by using (10)-(12). The final ranking is shown in Table 4.

Ultimately, full adaptive traffic management systems (A4) has become the most desirable strategy among four alternatives with the final performance value; while network communication systems (A2), security and emergency systems (A3) and intelligent public transport systems (A1) have positioned at the second, third and fourth ranks with 0.642, 0.584 and 0.551 as the final performance values, respectively. 
Table 3.The Final Criteria Weights

\begin{tabular}{|c|c|c|c|c|}
\hline $\begin{array}{l}\text { Main } \\
\text { Criteria }\end{array}$ & Weights & $\begin{array}{l}\text { Sub- } \\
\text { Criteria }\end{array}$ & Weights & $\begin{array}{l}\text { Global } \\
\text { Weights }\end{array}$ \\
\hline \multirow{5}{*}{$\mathrm{C} 1$} & \multirow{5}{*}{0.089} & C11 & 0.286 & 0.025 \\
\hline & & $\mathrm{C} 12$ & 0.128 & 0.011 \\
\hline & & $\mathrm{C} 13$ & 0.078 & 0.007 \\
\hline & & $\mathrm{C} 14$ & 0.114 & 0.010 \\
\hline & & $\mathrm{C} 15$ & 0.394 & 0.035 \\
\hline \multirow{5}{*}{$\mathrm{C} 2$} & \multirow{5}{*}{0.092} & $\mathrm{C} 21$ & 0.275 & 0.025 \\
\hline & & $\mathrm{C} 22$ & 0.054 & 0.005 \\
\hline & & $\mathrm{C} 23$ & 0.138 & 0.013 \\
\hline & & $\mathrm{C} 24$ & 0.358 & 0.033 \\
\hline & & $\mathrm{C} 25$ & 0.176 & 0.016 \\
\hline \multirow{5}{*}{$\mathrm{C} 3$} & \multirow{5}{*}{0.405} & C31 & 0.219 & 0.089 \\
\hline & & C32 & 0.077 & 0.031 \\
\hline & & C33 & 0.052 & 0.021 \\
\hline & & C34 & 0.591 & 0.239 \\
\hline & & C35 & 0.060 & 0.024 \\
\hline \multirow{5}{*}{$\mathrm{C} 4$} & \multirow{5}{*}{0.414} & $\mathrm{C} 41$ & 0.192 & 0.080 \\
\hline & & $\mathrm{C} 42$ & 0.068 & 0.028 \\
\hline & & $\mathrm{C} 43$ & 0.042 & 0.017 \\
\hline & & $\mathrm{C} 44$ & 0.173 & 0.072 \\
\hline & & C45 & 0.526 & 0.218 \\
\hline
\end{tabular}

Table 4.The Final Ranking

\begin{tabular}{|l|l|l|l|l|l|}
\hline & NSP & NSN & AS & $\begin{array}{l}\text { Defuzz. } \\
\text { Value }\end{array}$ & Ranking \\
\hline A1 & $(0.527,0.695,0.700)$ & $(0.367,0.456,0.559)$ & $(0.447,0.575,0.630)$ & 0.551 & 4 \\
\hline A2 & $(0.818,0.988,1.194)$ & $(0.230,0.305,0.316)$ & $(0.524,0.647,0.755)$ & 0.642 & 2 \\
\hline A3 & $(0.691,0.840,0.890)$ & $(0.303,0.385,0.396)$ & $(0.497,0.618,0.637)$ & 0.584 & 3 \\
\hline A4 & $(0.273,0.359,0.389)$ & $(0.845,1.020,1.136)$ & $(0.559,0.689,0.762)$ & 0.670 & 1 \\
\hline
\end{tabular}




\section{Conclusion}

The direction of the world in terms of ITS is obvious. Countries with high economic levels will make great strides in this area and use technology at the highest level. It is understood how much the ITS is needed if the material and spiritual losses that are caused by traffic accidents and congestions in our country are taken into account. It is important to choose the right strategy to implement the required system.

In this study, strategic analysis of ITS is proposed with analytic methods. Firstly, the proposed ITS model is structured with literature review and expert opinions. After that, this model is evaluated MCDM methods such as fuzzy AHP and fuzzy EDAS to calculate criteria weights and evaluate alternative strategies, respectively. According to results, the most appropriate strategy is "Full adaptive traffic management systems (A4)".

The subject of ITS strategy selection can be advanced in future studies by increasing the number of criteria and the decision-makers or using different decision-making methods. Another perspective can be to consider uncertainty using advanced fuzzy approach or use aggregation methods for group decision making.

\section{Acknowledgment}

This study is financially supported by Galatasaray University Research Fund. The authors kindly express their appreciation for the support of industrial experts.

\section{Reference}

Ayağ, Z. (2005). A Fuzzy AHP-Based Simulation Approach To Concept Evaluation In A NPD Environment. IIE transactions, 37(9), 827-842.

Bacciu, D., Carta, A., Gnesi, S., \&Semini, L. (2017). An Experience In Using Machine Learning For Short-Term Predictions In Smart Transportation Systems. Journal of Logical and Algebraic Methods in Programming, 87, 52-66.

Bask, A., Spens, K., Stefansson, G., \&Lumsden, K. (2009). Performance Issues Of Smart Transportation Management Systems. International Journal of Productivity and Performance Management.

Büyüközkan, G., and Çifçi, G. (2012). A Combined Fuzzy AHP And Fuzzy TOPSIS Based Strategic Analysis Of Electronic Service Quality In Healthcare Industry. Expert systems with applications, 39(3), 2341-2354.

Catapult. (2014). Exploring Intelligent Mobility.

Civitas. (2015). Intelligent Transport Systems And Traffic Management In Urban Areas, Policy Note.

Dia, H., Panwai, S. (2014, December). Intelligent Mobility for Smart Cities: Driver Behaviour Models for Assessment of Sustainable Transport. In 2014 IEEE Fourth International Conference on Big Data and Cloud Computing (pp. 625-632). IEEE.

Ghorabaee, M. K., Zavadskas, E. K., Amiri, M., \&Turskis, Z. (2016). Extended EDAS Method For Fuzzy Multi-Criteria Decision-Making: An Application To Supplier Selection. International Journal of Computers Communications \& Control, 11(3), 358-371.

Ilıcalı, M., Toprak, T., Özen, H., Tapkın, S., Öngel, A., Camkesen, N, and Kantarc1, M. (2016). Akıcı- Güvenli Trafik için Akıllı Ulaşım Sistemleri. 
Keshavarz Ghorabaee, M., Zavadskas, E. K., Olfat, L., \&Turskis, Z. (2015). Multi-Criteria Inventory Classification Using A New Method Of Evaluation Based On Distance From Average Solution (EDAS). Informatica, 26(3), 435-451.

Kim, H. J., Lee, J., Park, G. L., Kang, M. J., \& Kang, M. (2010, September). An Efficient Scheduling Scheme On Charging Stations For Smart Transportation. In International Conference on Security-Enriched Urban Computing and Smart Grid (pp. 274-278). Springer, Berlin, Heidelberg.

Kirch, M., Poenicke, O., and Richter, K. (2017). RFID in Logistics and ProductionApplications, Research and Visions for Smart Logistics Zones. Procedia Engineering, 178, 526-533.

Kolosz, B., Grant-Muller, S., and Djemame, K. (2013). Modelling Uncertainty In The Sustainability Of Intelligent Transport Systems For Highways Using Probabilistic Data Fusion. Environmental Modelling \& Software, 49, 78-97.

Kumbhar, M. A. (2012). Wireless Sensor Networks: A Solution For Smart Transportation. Journal of Emerging Trends in Computing and Information Sciences, 3(4).

Kutlu Gündoğdu, F., Kahraman, C., \&Civan, H. N. (2018). A Novel Hesitant Fuzzy EDAS Method And Its Application To Hospital Selection. Journal of Intelligent \& Fuzzy Systems, (Preprint), 1-13.

Pomorel, J. C., \& Romero, S. B. (2000). Multicriterion Decision in Management. Principle and Practice.

Saaty, T. L. (1980). The analytic hierarchy process McGraw-Hill. New York, 324.

Schewel, L., and Kammen, D. M. (2010). Smart Transportation: Synergizing Electrified Vehicles And Mobile Information Systems. Environment, 52(5), 24-35.

T. C. Ministry of Transport, Maritime Affairs and Communications (UHDB). (2014). National Intelligent Transportation Systems Strategy Document and Action Plan: 2014-2023.

UNECE, (2012). Intelligent Transport Systems (ITS) For Sustainable Mobility.

Wang, F. Y. (2010). Parallel Control And Management For Intelligent Transportation Systems: Concepts, Architectures, And Applications. IEEE Transactions on Intelligent Transportation Systems, 11(3), 630-638.

Wang, M., and Kexin, L. (2013). Transportation model application for the planning of low carbon city-take Xining city in China as example. Procedia Computer Science, 19, 835-840.

Yardım, M. S. and Akyıldız, G. (2005). Intelligent Transportation Systems and Applications in Turkey. 6th Transportation Congress Proceeding, Istanbul: TMMOB Civil Engineers.

Zanelli, P. (2016). Intelligent Mobility. CATAPULT Transport Systems Report.

Zhang, J., Wang, F. Y., Wang, K., Lin, W. H., Xu, X., \& Chen, C. (2011). Data-driven intelligent transportation systems: A survey. IEEE Transactions on Intelligent Transportation Systems, 12(4), 1624-1639. 